\title{
Problems Of Females' Progression In Higher Education: Perceptions Of Female University Students
}

\author{
Muhammad Amin \\ Department of Education \\ University of Education
}

Ijaz Ahmad Tatlah

\&

Arfa Afghani

Department of Education

University of Education, Township Campus

\begin{abstract}
The study aims to investigate the barriers that hinder in the progress of females' higher education. The study adopted a mixed methods approach. The quantitative data is collected from 200 female students of a Pakistani public university through a structured questionnaire, whereas to generate the qualitative data semi-structured interviews are conducted from 15 female students from the same group. The findings highlight ignorant parents as major barrier in the way of females' higher education. Moreover, cultural norms, low socio-economic status, unavailability of universities in remote areas, and stereotype thinking of families are also pointed out as main barriers of females' progression in higher education. Some implications for policy are offered and suggestions for future research are proposed.
\end{abstract}

Keywords: Females' Problems, Higher Education, Pakistani Societal Context

$$
\begin{aligned}
& \text { تلخيص }
\end{aligned}
$$

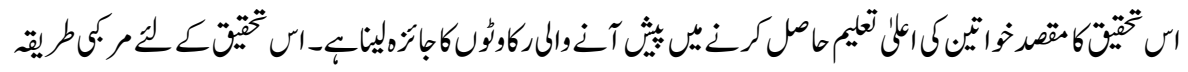

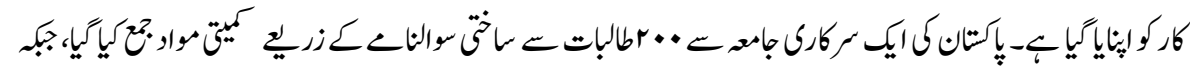

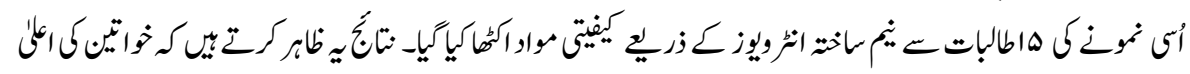

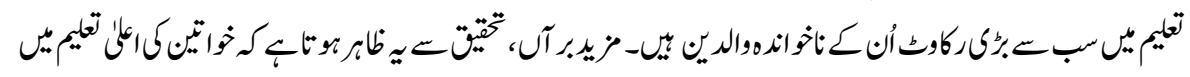

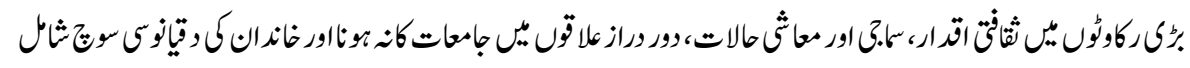

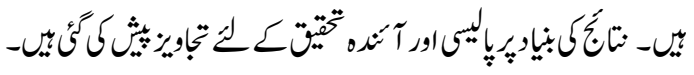

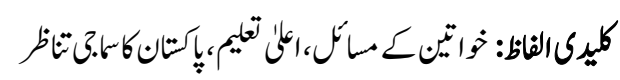




\section{Introduction}

Females play critical role in the society. There are many negative aspects prevailing in our society such as hunger, poverty and ignorance but females' higher education seems more important. Females are considered dependent and this dependency occurs mainly because of the lack of higher education. The issue of illiteracy of females is today's challenge, and more specifically lack of females' higher education is accepted by all development agencies as major challenge. If females are highly educated, it is beneficial for themselves and their families as well. It is proven through studies that wages of females increase by $10-20 \%$ by increasing one year of education (Herz \& Sperling, 2004:22) and can have a positive impact on the welfare of their families. Educated females have lower health risks related to pregnancy and they can take care of their children in a better way. An educated female pays more attention towards the education of her children especially of her daughters. Ratio of domestic violence is seen less in educated females. Pakistani society is considered less likely to pay attention towards females' higher education because of various reasons such as it is male dominant, has firm and negative conventions/customs, gender disparity, conservatism, religions misperception, and female harassment.

Male and female has the equal right to get education and to enjoy the benefits of educational opportunities (Terry \& Thomas, 1997). Knowledge and skills contribute meaningfully to the society and these can be gained through education. When we talk about laws and policies, it should be understood that resources and programs for both male and female students' must be there. It is seen that mostly uneducated females become a victim of violence as compared to the educated females because they do not know how to protect themselves as they are unaware of their rights (Heise et al., 1999). Females' higher education enhances the economic development of the country. The more the females earn, the more the income of the country will rise (Stephan, 2002). In Pakistan, girls are restricted to get higher education and gender-based discrimination in education is also there, that is why the females are lagging in almost every profession. In addition to the above mentioned reasons, there are also some other factors, that hinder the females' higher education, such as gender injustice, posting at distant from their own houses, transport problems, political insecurities and unnecessary political interference.

Hamid (1993) observed that cultural traditions of Pakistan keep the girls away from education as people make their own rules perhaps based on the culture and label them as the religious norms of the society (Khan \& Ali, 2005). Similarly, low school enrolment in rural Punjab adds to the low ratio of females in higher education, as the figures show that the Net Enrolment Rate (NER) of females at secondary level in rural Punjab is 7\% as compared to $24 \%$ and $17 \%$ in major cities and other urban areas (Punjab Bureau of Statistics (PBS), 2005). In the constitution of Pakistan, females' education is considered 
as important as for males, and free elementary/secondary education to remove illiteracy in females is compulsory. Moreover, it is important to make technical and professional education/higher education equally accessible to all on the basis of merit (Constitution of Pakistan, Article-37). However, almost in all the areas of the four provinces of Pakistan, females are being neglected in this regard.

In traditional societies like Pakistani, females are supposed to do only household work and to look after the children that cause the low parental investment in the education of their daughters and consequently it hinders the females to move towards higher education. Conservative parents usually do not want to spend more money on females because of the traditional thinking that the leading role in professional and social life is limited to males only. According to them, girls are more inclined towards household work comparative to boys (Colclough et al., 2000). Concept of co-education is also taken in wrong sense by mostly parents. They think that co-education is not educating girls and boys rather it is spoiling them in the name of liberalism. In some extreme cases, around the globe, females are considered useless except the physical object for male sexual desire (Bartky, 1990; Fredrickson \& Roberts, 1997).

\section{Review of Literature}

Pakistani society is a male dominant that is why males are encouraged in every field of life whether it is education or profession. Literacy rate of male is more than that of females because investment in human development is more towards men (Skalli, 2001). It is observed that females have fewer chances to get higher education as well as technical education and to enter in professional life also (Khan, 2007). Ronning (2000) highlights that the power issue is at the core of the nexus under debate that makes the males superior and to tackle this superiority is to realize the importance of females' higher education. Females' higher education plays an extremely serious and vital role in the improvement of a country, particularly in the monetary advancement of a nation. However, economic and sex partialities, as mentioned above, are major hindrances in the way of females to get higher education and because of these reasons females are not able to play a dynamic role in the improvement of society (Parveen, 2008).

In 2006-2008, Inter-Parliamentary Union (IPU) conducted a survey and reveal that females and males legislators have different interests and perspectives of life. This highlights that policy with reference to females should be framed by females because they can easily highlight the general concerns of their sex. So, this study may be significant for female policy makers at government and Higher Education Commission (HEC) level to address the females' problems that they are facing in the way of getting higher education. This study may add to the theory/literature already exist with reference to females' progression in higher education. Keeping in view the focus and significance 
of the study, the research question under investigation is: What are the barriers in the progress of females' higher education? The next section presents literature review on some of the related factors such as cultural norms, low socio-economic, ignorant parents, unavailability of universities, and stereotype thinking of families that hinder the females' progression in higher education.

Cultural Norms: Culture is a vast terminology and it covers every aspect of life. Culture is one of the major criteria that define standards of behaviors (Crapo, 2000). A culture is a complex system of norms of set standards which all the members of society generally follow. Though Pakistan is itself signatory of UN Education for All (EFA) Framework for Action (2000) Document, which emphasis on females' higher education, but the efforts to achieve the target of higher education for females are still unsatisfactory. If we see females' literacy rate, it clearly shows that priority is given to men as compared to females (Skalli, 2001) because of male dominance in our culture. Females are restricted to get higher education and other professional degrees as cultural norms play the role of glass ceiling in the way of females' higher education (Khan, 2007). Pakistani society is a typical society and it has conservative cultural norms which has placed females in the category of mothers and house wives while males are placed in the category of leaders of home. Usually parents perceive that leadership is only limited to the male members of the society. Hence, females should not be indulged in higher education. This discrimination starts at early age, when girls are engaged in household works, they are given training to always sacrifice for their male siblings so they become habitual of it. Same is the case in their higher education when they are restricted for it by saying that you have to go to your husband's home and it is useless to carry on your studies.

Early marriages of females are also very common in Pakistani culture. Mostly stereotype parents feel their daughters a burden on them and they want to get rid of this burden as soon as possible. Generally, in such societies males are considered as earning hands and females as the guardians of home. There are strong political, societal and cultural pressures that shape the male dominant society of Pakistan with rigid traditions and conservative thinking patterns for example it is against the family respect if females' go for higher education especially in co-education setup. In Pakistan, willingness of families towards females' higher education is very low because of the negative thinking. According to such families, females should attain the Islamic education while school/college/university education is prohibited for them. Females are bounded in homes in the name of Islam and culture.

Low Socio-Economic Status: Low socio-economic status is also a strong barrier in the way of females' higher education. Families who have low income, they give priority to boys' higher education as compare to females. Such types of parents think, in the end girls have to go to husband's home so it is useless to spend money on females' higher 
education. So, the girls are restricted and they are indulged in household activities (Khalid \& Mukhtar's, 2002). Furthermore, females' higher education is comparatively more expensive than males, as females mostly use private transport and parents with low socio-economic cannot afford it.

Ignorant Parents: One of the tragedies happen to females is that in some cases the fate of the females is decided solely by the parents, especially when parents are low qualified or ignorant, in all walks of life whether it is education, marriage or professional life. Sending of females to higher level of education is considered against the honor of parents. Ignorant parents consider boys as lucky charms for them and girls as a burden, therefore girls are kept illiterate (Rizvi, 1980). Ignorant parents are keen about the education of boys and consider the girls as liability, so that their investment in girls' higher education is very low and insufficient. Ignorant parents are not interested to send their daughters in universities and at an early age they make their daughter aware that she is only a temporary member of the family, and any skill she learns will benefit not her own family but her in-laws, therefore a very few parents prefer their daughters to send them in vocational institutes (Rizvi, 1980). Another hurdle in the way of females' higher education is early marriage of girls that is because of parents' ignorance. After marriage, young girl's right to gain entrance to formal and even non-formal education is extremely restricted due to house management responsibility, childbearing and societal customs that view marriage and education as contrary (Mathur, et al, 2003). The societal beliefs and practices of the family leader, who is male usually in societies like Pakistan, play a major role in deciding whether females will go for higher education or not because decision making is in his hand (Keng, 2004; Buchmann \& Hannum, 2001).

Unavailability of Universities: The unavailability of higher education institutions in remote areas is another reason because of which females are not getting higher education. Female student face many issues, such as traveling long commute on private transport and residing in hostel especially when it is private, are expensive but more importantly these convert into security issues of girls and this is true to a large extent. Generally, female students are not comfortable to travel in public transport on daily basis because of sexual harassment and bullying problems from males. There are a number of girl's sexual abuse cases which have been seen and these become the basis of not sending females to the institutions far from homes. Residential and commercial development like hotels around the females' institutions is adding into this problem (Dhakku, 2012). Unfortunately, restrictions on the movement of females, prohibiting from education, is the most widely practiced method for handling the issue of females' security.

Stereotype Thinking of Families: Pakistani society is a stereotype society as male members are always given better education than females. Mostly people think that males have to be the source of income so they should be given higher education, while females 
have to serve her parents and after that her in-laws so females are to get the know-how of domestic skills and there is no need to send them in institutes for higher education (Khan, 2007). As it is socially expected from females that they would perform household tasks and it takes less effort to learn these skills, so females have lesser right than males on health and education facilities, and food resources. Males are considered as the security assurance for family so stereotype families invest in the higher education of their sons. According to these parents this investment would be more beneficial in their old age. If females are highly educated than their husbands, the stereotype husbands consider themselves at low level. According to them, females should not be highly educated and females should be kept at low level. When a girl born, it is viewed as a terrible sign for the entire family but when a boy is born it is celebrated with incredible ceremony and show. The common concept about females is that they are considered and treated as the property of their spouse and a female as a wife cannot challenge her husband. People with such mentality do not support co-education. In Pakistani society, boys are trained for office jobs, politics, army and business while girls are trained for domestic work and how to serve the elders especially the male members of the society. The co-education is perceived by conservative parents a threat to this conventional division of labor. Co-education is considered a symbol of liberalism in Pakistan. Females are restricted to get higher education.

\section{Methodology}

The mixed methods approach has been adopted to conduct the study, so paradigm of this research is pragmatism. Data was collected/generated from one Lahore based campus of a public university of the Punjab. Female students of Master and M.Phil level of the selected university were defined as target population of the study. Selection of the university, campus and respondents is convenience based. Structured questionnaire has been used to collect quantitative data from 200 students (100 Master level and 100 M.Phil level), whereas qualitative data consists of 15 interviews from the same group. Both the structured questionnaire and semi-structured interview protocol were selfdeveloped and were made final through expert opinion and pilot testing. The language of both the tools was English. Permission from the registrar of the selected university and from the principal of the selected campus was sought before the administration of the tools. Moreover, informed consent form was attached with the questionnaire, and for interview, respondents were personally requested and then interviewed whoever was willing. However, seven M.Phil and eight Master level students were interviewed. The quantitative data is described through frequency and percentage, and qualitative data is analyzed through thematic analysis. Thematic analysis was used because themes were pre-defined in the semi-structured protocol.

\section{Data Presentation and Findings}

This section contains quantitative and qualitative data and findings followed by discussion. 
Table: 1

Cultural Norms

\begin{tabular}{|l|c|c|c|c|}
\hline \multirow{2}{*}{ Questionnaire Items } & $\begin{array}{c}\text { SA } \\
\text { (1) }\end{array}$ & $\begin{array}{c}\mathbf{A} \\
\mathbf{( 2 )}\end{array}$ & $\begin{array}{c}\mathbf{D} \\
\mathbf{( 3 )}\end{array}$ & $\begin{array}{c}\text { SD } \\
\text { (4) }\end{array}$ \\
\cline { 2 - 5 } & $\begin{array}{c}\text { Frequency } \\
\text { (Percentage) }\end{array}$ & $\begin{array}{c}\text { Frequency } \\
\text { (Percentage) }\end{array}$ & $\begin{array}{c}\text { Frequency } \\
\text { (Percentage) }\end{array}$ & $\begin{array}{c}\text { Frequency } \\
\text { (Percentage) }\end{array}$ \\
\hline $\begin{array}{l}\text { 1.Due to the cultural norms, } \\
\text { most of the parents expect } \\
\text { their daughters to look } \\
\text { after the house and pay no } \\
\text { attention to their higher } \\
\text { education. }\end{array}$ & $\begin{array}{c}62 \\
(32.5 \%)\end{array}$ & $\begin{array}{c}64 \\
(33.5 \%)\end{array}$ & $\begin{array}{c}42 \\
(22 \%)\end{array}$ & $(12 \%)$ \\
\hline $\begin{array}{l}\text { 2. Some parents are more } \\
\text { focused towards domestic } \\
\text { skills of their daughters } \\
\text { like cooking, sewing as } \\
\text { compared to higher } \\
\text { education. }\end{array}$ & \begin{tabular}{c}
$(24.1 \%)$ \\
\hline
\end{tabular} & $(33 \%)$ & $(24.6 \%)$ & $(18.3 \%)$ \\
\hline
\end{tabular}

$66 \%$ of the participants, when agree and strongly agree are combined, highlight that due to the cultural norms, most of the parents expect their daughters to look after the house and pay no attention to their higher education. However, $34 \%$ of the respondents, when disagree and strongly disagree are combined, oppose this view. On item no 2, 57.1\% of the participants were of the view that some parents are more focused towards domestic skills of their daughters like cooking, sewing as compared to higher education; while $42.9 \%$ of the participants contradict this view.

The qualitative data support the findings of quantitative data as is evidenced from then below presented response:

I think yes, ...our cultural norms are barriers. ... peoples' views about females' higher education are very narrow [restricted]. Those females who get higher education, they cannot give proper time to their homes, their married life is also affected because of over-burden, they are much indulge in outside as compare to home. Actually the people who did not get higher education, still they have wrong concepts about females' higher education. (Respondent (R) 12) ...limits are always there which are mostly religious and people only restrict their females to get higher education in the name of religion which has become a part of our culture. (R7) 
Table: 2

Socio-Economic Status

\begin{tabular}{|c|c|c|c|c|}
\hline \multirow{2}{*}{ Questionnaire Items } & $\begin{array}{l}\text { SA } \\
\text { (1) }\end{array}$ & $\begin{array}{l}\text { A } \\
\text { (2) }\end{array}$ & $\begin{array}{l}\text { D } \\
\text { (3) }\end{array}$ & $\begin{array}{l}\text { SD } \\
\text { (4) }\end{array}$ \\
\hline & \begin{tabular}{|c|} 
Frequency \\
(Percentage)
\end{tabular} & $\begin{array}{c}\text { Frequency } \\
\text { (Percentage) }\end{array}$ & $\begin{array}{c}\text { Frequency } \\
\text { (Percentage) }\end{array}$ & $\begin{array}{c}\text { Frequency } \\
\text { (Percentage) }\end{array}$ \\
\hline $\begin{array}{l}\text { 1. Money is the main hindrance } \\
\text { in the way of females' } \\
\text { progress in higher education. }\end{array}$ & $\begin{array}{c}47 \\
(24.6 \%)\end{array}$ & $\begin{array}{c}90 \\
(47.1 \%)\end{array}$ & $\begin{array}{c}37 \\
(19.4 \%)\end{array}$ & $\begin{array}{c}17 \\
(8.9 \%)\end{array}$ \\
\hline $\begin{array}{l}\text { 2.Low socio-economic status } \\
\text { hinders the females' higher } \\
\text { education. }\end{array}$ & $\begin{array}{c}50 \\
(26.2 \%)\end{array}$ & $\begin{array}{c}79 \\
(41.4 \%)\end{array}$ & $\begin{array}{c}40 \\
(20.9 \%)\end{array}$ & $\begin{array}{c}22 \\
(11.5 \%)\end{array}$ \\
\hline $\begin{array}{l}\text { 3. Higher education is expensive } \\
\text { regarding hostel expenditures, } \\
\text { tuition fee and transportation } \\
\text { that only elite class and feudal } \\
\text { have a privilege to get them. }\end{array}$ & $\begin{array}{c}57 \\
(29.8 \%)\end{array}$ & $\begin{array}{c}71 \\
(37.2 \%)\end{array}$ & $\begin{array}{c}39 \\
(20.4 \%)\end{array}$ & $\begin{array}{c}24 \\
(12.6 \%)\end{array}$ \\
\hline
\end{tabular}

The data highlight that $71.7 \%$ of the respondents pointed out money as the main hindrance in the way of females' progress in higher education. On the other hand, $28.3 \%$ of the respondents deny this opinion. In response to item no $2,67.6 \%$ of the participants were of the view that Low socio-economic status hinders the females' higher education. While $32.4 \%$ of the participants, negate this view. For item no 3, more than half $(67 \%)$ of the respondents believed that Higher education is expensive because of hostel expenditures, tuition fee and transportation that only elite class and feudal have a privilege to get them; whereas, $33 \%$ of the respondents were in the opposition of this view.

The qualitative data supports this view as the below response shows:

Yes, according to me, socio-economic status becomes a barrier in females' higher education, parents think that there is no need of females' higher education as females have to go their husbands' home and it is useless for us. Secondly, dowry is also common in our society so parents consider it a double burden as we give our daughters higher education side by side their marriage. $(\mathrm{R} 9,12)$

One of the respondents has explained this opinion in some other way:

Yes, economy is the major factor which sometimes creates hurdles in the way of females' higher education. If they have money, parents will spend on their daughters' education, especially on their higher education. But in this matter awareness should be there. Some parents have high socio-economic status but they do not care about females' higher education. (R6) 
Table: 3

Ignorant Parents

\begin{tabular}{|c|c|c|c|c|}
\hline \multirow{2}{*}{ Questionnaire Items } & $\begin{array}{l}\text { SA } \\
\text { (1) }\end{array}$ & $\begin{array}{l}\mathrm{A} \\
\text { (2) }\end{array}$ & $\begin{array}{l}\text { D } \\
\text { (3) }\end{array}$ & $\begin{array}{l}\text { SD } \\
\text { (4) }\end{array}$ \\
\hline & \begin{tabular}{|c|} 
Frequency \\
(Percentage)
\end{tabular} & $\begin{array}{c}\text { Frequency } \\
\text { (Percentage) }\end{array}$ & $\begin{array}{c}\text { Frequency } \\
\text { (Percentage) }\end{array}$ & $\begin{array}{c}\text { Frequency } \\
\text { (Percentage) }\end{array}$ \\
\hline $\begin{array}{l}\text { 1. Some parents pay more attention } \\
\text { towards boys' education because } \\
\text { they consider that boys earn for } \\
\text { them in future while girls go to } \\
\text { their husband's place and give no } \\
\text { benefit. }\end{array}$ & $\begin{array}{c}49 \\
(25.7 \%)\end{array}$ & $\begin{array}{c}89 \\
(46.6 \%)\end{array}$ & $\begin{array}{c}36 \\
(18.8 \%)\end{array}$ & $\begin{array}{c}17 \\
(8.9 \%)\end{array}$ \\
\hline $\begin{array}{l}\text { 2. Illiterate parents hinder in the } \\
\text { progress of females' higher } \\
\text { education as they are unaware of } \\
\text { the importance of education. }\end{array}$ & $\begin{array}{c}61 \\
(31.9 \%)\end{array}$ & $\begin{array}{c}66 \\
(34.6 \%)\end{array}$ & $\begin{array}{c}47 \\
(24.6 \%)\end{array}$ & $\begin{array}{c}17 \\
(8.9 \%)\end{array}$ \\
\hline $\begin{array}{l}\text { 3. Narrow minded parents do not } \\
\text { allow their daughters to get } \\
\text { professional and technical } \\
\text { degrees as these degrees lead } \\
\text { towards a professional life. }\end{array}$ & $\begin{array}{c}53 \\
(27.7 \%)\end{array}$ & $\begin{array}{c}68 \\
(35.6 \%)\end{array}$ & $\begin{array}{c}46 \\
(24.1 \%)\end{array}$ & $\begin{array}{c}24 \\
(12.6 \%)\end{array}$ \\
\hline $\begin{array}{l}\text { 4. An early marriage of girls is also } \\
\text { a barrier for their higher } \\
\text { education. }\end{array}$ & $\begin{array}{c}47 \\
(24.6 \%)\end{array}$ & $\begin{array}{c}65 \\
(34 \%)\end{array}$ & $\begin{array}{c}57 \\
(29.8 \%)\end{array}$ & $\begin{array}{c}22 \\
(11.5 \%)\end{array}$ \\
\hline
\end{tabular}

A reasonable number of female students $(72.3 \%)$ believed that some parents pay more attention towards boys' education because they consider that boys earn for them in future while girls go to their husband's place and give no benefit. However, $27.7 \%$ of the female students respond negatively to this view. For item no $2,66.5 \%$ of the respondents highlighted that Illiterate parents hinder in the progress of females' higher education as they are unaware of the importance of education. While $33.5 \%$ of the respondents reject this view. In response to item no $3,63.3 \%$ of the participants were of the view that Narrow minded parents do not allow their daughters to get professional and technical degrees as these degrees lead towards a professional life. On the other hand $36.7 \%$ of the participants oppose this view. For item no $4,58.6 \%$ of the participants highlight the view that an early marriage of girls is also a barrier for their higher education. But $41.3 \%$ of the respondents negate this opinion.

In qualitative data, many participants highlighted that ignorant parents support the above findings and consider females' higher education as an unimportant thing as is evidenced from the below response:

Ignorant parents think females' higher education is a useless thing because in the end, females are born for domestic work and females have to marry and would go to their husbands' home. Sometimes, parents think if females are highly educated, it would be difficult to find a perfect and highly educated groom for them.... and it is the 
tragedy of our society that boys are not as educated as our girls are. (R12) Ignorant parents do not know how females can contribute in country's progress...they do not have awareness. Because they did not see the university life and they think if we send our females at university, it is only wastage of time. (R11)

Table: 4

Unavailability of Universities in Remote Areas

\begin{tabular}{|l|c|c|c|c|}
\hline \multicolumn{1}{|c|}{ Questionnaire Items } & $\begin{array}{c}\text { SA } \\
\text { (1) }\end{array}$ & $\begin{array}{c}\text { A } \\
\text { (2) }\end{array}$ & $\begin{array}{c}\text { D } \\
\text { (3) }\end{array}$ & $\begin{array}{c}\text { SD } \\
\text { (4) }\end{array}$ \\
\cline { 2 - 5 } & $\begin{array}{c}\text { Frequency } \\
\text { (Percentage) }\end{array}$ & $\begin{array}{c}\text { Frequency } \\
\text { (Percentage) }\end{array}$ & $\begin{array}{c}\text { Frequency } \\
\text { (Percentage) }\end{array}$ & $\begin{array}{c}\text { Frequency } \\
\text { (Percentage) }\end{array}$ \\
\hline $\begin{array}{l}\text { 1. Unavailability of universities in } \\
\text { small cities can be a hurdle for } \\
\text { females' in higher education. }\end{array}$ & $\begin{array}{c}39 \\
(20.4 \%)\end{array}$ & $\begin{array}{c}75 \\
(39.3 \%)\end{array}$ & $\begin{array}{c}51 \\
(26.7 \%)\end{array}$ & $\begin{array}{c}26 \\
(13.6 \%)\end{array}$ \\
\hline $\begin{array}{l}\text { 2. Parents feel uncomfortable to } \\
\text { send their daughters in hostels } \\
\text { due to the security reason. }\end{array}$ & $\begin{array}{c}47 \\
(24.6 \%)\end{array}$ & $\begin{array}{c}80 \\
(41.9 \%)\end{array}$ & $\begin{array}{c}40 \\
(20.9 \%)\end{array}$ & $\begin{array}{c}24 \\
(12.6 \%)\end{array}$ \\
\hline $\begin{array}{l}\text { 3. Transportation affects the } \\
\text { females' higher education if } \\
\text { universities and colleges are far } \\
\text { from their houses as it is quite } \\
\text { risky and costly as well. }\end{array}$ & 44 & 77 & 57 & 13 \\
\hline $\begin{array}{l}\text { 4. Pakistan spends around 2\% of } \\
\text { GDP on education which } \\
\text { provides very low percentage to } \\
\text { spend on the higher education. }\end{array}$ & $\begin{array}{c}(23 \%) \\
(40.3 \%)\end{array}$ & $(29.8 \%)$ & $(6.8 \%)$ \\
\hline
\end{tabular}

More than half $(59.7 \%)$ of the respondents believed that unavailability of universities in small cities can be a hurdle for females' in higher education; $40.3 \%$ of the respondents deny this view. For item no 2, again more than half $(66.5 \%)$ of the respondents thought that parents feel uncomfortable to send their daughters in hostels due to the security reason, with $33.5 \%$ perceiving this view in an opposite way. On item no 3 , the data show that $63.3 \%$ of the participants believed that transportation affects the females' higher education if universities and colleges are far from their houses as it is quite risky and costly as well. However, $36.6 \%$ of the participants contradict with this view. Moreover the data, for item 4, demonstrate that $67.5 \%$ of the respondents thought that Pakistan spends around $2 \%$ of GDP on universities which provides very low percentage to spend on the higher education, While $32.4 \%$ of the respondents oppose this view.

Unavailability of universities in remote areas was also seen as main hurdle in the way of females' higher education:

Unavailability of universities hinders[sic] females' higher education and it is a big problem in remote areas. Parents do not send their daughters in universities only because of the long distance. Moreover 
females face conveyance problems. Higher education costs much and parents cannot bear the expenses. (R1) Parents are not ready to send girls as they think, girls have to face a lot of problems of transportation, residence, security and how they manage themselves in hostels. That's why parents do not send their daughters. (R15)

Table: 5

Stereotype Thinking of Families

\begin{tabular}{|c|c|c|c|c|}
\hline \multirow[b]{2}{*}{ Questionnaire Items } & $\begin{array}{l}\text { SA } \\
\text { (1) }\end{array}$ & $\begin{array}{c}\text { A } \\
(2)\end{array}$ & $\begin{array}{c}\text { D } \\
(3)\end{array}$ & $\begin{array}{l}\text { SD } \\
(4)\end{array}$ \\
\hline & $\begin{array}{c}\text { Frequency } \\
\text { (Percentage) }\end{array}$ & $\begin{array}{c}\text { Frequency } \\
\text { (Percentage) }\end{array}$ & $\begin{array}{c}\text { Frequency } \\
\text { (Percentage) }\end{array}$ & $\begin{array}{c}\text { Frequency } \\
\text { (Percentage) }\end{array}$ \\
\hline $\begin{array}{l}\text { 1. Stereotype thinking of parents } \\
\text { affect the females' higher } \\
\text { education since they feel that } \\
\text { educated girls visualize themselves } \\
\text { superior and cannot find suitable } \\
\text { grooms. }\end{array}$ & $\begin{array}{c}48 \\
(25.1 \%)\end{array}$ & $\begin{array}{c}79 \\
(41.4 \%)\end{array}$ & $\begin{array}{c}38 \\
(19.9 \%)\end{array}$ & $\begin{array}{c}26 \\
(13.6 \%)\end{array}$ \\
\hline $\begin{array}{l}\text { 2. Some parents restrict the } \\
\text { movement of their daughters inside } \\
\text { the house in the name of religion. }\end{array}$ & $\begin{array}{c}55 \\
(28.8 \%)\end{array}$ & $\begin{array}{c}75 \\
(39.3 \%)\end{array}$ & $\begin{array}{c}44 \\
(21.5 \%)\end{array}$ & $\begin{array}{c}20 \\
(10.5 \%)\end{array}$ \\
\hline $\begin{array}{l}\text { 3. Co-education becomes an } \\
\text { obstacle in the way to females' } \\
\text { higher education as parents do } \\
\text { not allow their daughters to study } \\
\text { with the boys. }\end{array}$ & $\begin{array}{c}60 \\
(31.4 \%)\end{array}$ & $\begin{array}{c}74 \\
(38.7 \%)\end{array}$ & $\begin{array}{c}41 \\
(21.5 \%)\end{array}$ & $\begin{array}{c}16 \\
(8.4 \%)\end{array}$ \\
\hline $\begin{array}{l}\text { 4. A stereotype husband thinks he } \\
\text { should be more educated than his } \\
\text { wife. }\end{array}$ & $\begin{array}{c}79 \\
(41.4 \%)\end{array}$ & $\begin{array}{c}56 \\
(29.3 \%)\end{array}$ & $\begin{array}{c}38 \\
(19.9 \%)\end{array}$ & $\begin{array}{c}18 \\
(9.4 \%)\end{array}$ \\
\hline
\end{tabular}

The data show that, in response to item $1,66.5 \%$ of the respondents believed that Stereotype thinking of parents affects the females' higher education since they feel that educated girls visualize themselves superior and cannot find suitable grooms; $33.5 \%$ of the respondents contradict with this view. For item no 2, when participants were asked that some parents restrict the movement of their daughters inside house in the name of religion, $68.1 \%$ of the participants agreed with it. While $32 \%$ of the participants disagreed with this view. In reply to item no $3,70.1 \%$ of the participants were of the view that co-education becomes an obstacle in the way to females' higher education as parents do not allow their daughters to study with the boys. However, $29.9 \%$ of the participants reject this view.

Qualitative data support these findings in the following way:

Stereotype thinking of families definitely oppose the females' higher education..., if previous generation is illiterate, families think next 
generation would also be alike. So it is a hurdle in the way of females' progress in higher education. Females' are restricted to get higher education because some families think boys' higher education matters while girls' should only be perfect in domestic skills and they have to move in their husbands' home so it is the wastage of time and money to spend on females' higher education. (R1) Religious families do not want their females to go out of homes openly for studies [because] people...do gossips about their females [in a negative sense]. (R13)...[these] families exploit their females in the name of religion and... such people misuse the message of Islam [that]Islam does not allow females to get higher education. (R9\&5)

\section{Discussion}

Cultural norms are highlighted as barrier in the females' progression for higher education. Tembon \& Fort (2008) support these findings by arguing that girls are always provided low level education as compare to boys. Findings point out that Pakistan has a conservative male dominant society and has many cultural norms that prohibit females especially from higher education. This is supported by Himayatullah \& Parveen (1990) with the argument that low participation rate of females in higher education is because of different cultural barriers. In comparison to other countries, the situation is not much different because it was found that in 15 major states of India gender gaps are there with reference to higher education (Hirwav \& Mahadevia, 1996). Similar evidence has been found in the case of Zimbabwe as well (Mehretu, 2001).

In the present study, economic constraints are revealed as factor that influences parental decisions to send their boys to school as compared to girls with the argument that boys become the earning hand of parents in future. However, in order to strengthen the socioeconomic status and to run the home expenditures, males and females need to work together highlights the importance of females' higher education. The ratio of females' in higher education is very low in Pakistani context in spite of the fact that females' population is more than $50 \%$. This dilemma is also evidenced in Ghana where only $12 \%$ women were enrolled in the six public universities in the academic year 2000-2001 (National Council on Tertiary Education, 2006). Moreover, culturally females are considered as the dependent ones because there is male dominance in Pakistani society. Pakistan National Plan of Action for Women (1998) set a goal regarding gender equality and equity in education and it was due to achieve by 2013, however it still needs a lot to be done. In this regard, Pakistan can take the example of United States where females' number in higher education is rising and both genders are getting higher education no matter it is in co-educational set up or single-sex institutions (Datnow, et al, 2001). 
Furthermore current study shows that low enrolment of girls in higher education is mainly because of the unavailability of universities in remote areas of Punjab. This is supported by the previous study that highlight that females have limited access to higher education (Sathar, et al, 2000). Current study further point out that females face problems to move into distant institutions as compared to men because public transport is not available in remote territories of Punjab. Where public transport is available girls cannot use public transport as frequently and with peace of mind as compared to boys. There are security issues for females while travelling in public transport especially where females are not allowed to move alone culturally. Literature supports these findings (Ramachandran, 2010). Finally, stereotype thinking of families whether they are parents or they are husbands (if girls are married at an early age) pressurize females in different ways to not to go for higher education and quit that if they have started. In some cases female students are not allowed to even submit the final thesis once they got married. Rossi, (1987) support these findings by maintaining that Pakistani female has always been a victim with reference to progression in higher education. Gender based discrimination is also evidenced in some other countries of South Asia and Sub-Saharan Africa with respect to getting higher education.

\section{Conclusions}

The findings and conclusions of the present study have some implications for policy and practice. The study explored the barriers in the way of females' higher education. The findings of the present study illustrate that constraints in the way of females' higher education are there; however it is not limited to the Pakistan, barriers and restrictions are also there in some other Asian and African countries. Findings of the present study demonstrate that females had been through troublesome circumstances and facing social boundaries in getting entrance into higher education. These types of social boundaries are deep rooted in sex segregation focused around masculine structure of the overall Pakistani society specifically and international society in general. The findings from this study were supported by various researchers from different contexts (Terry \& Thomas, 1997; Sticht, 1994; Sticht \& McDonald, 1990).

It is further concluded from the present study that because of cultural norms, low socioeconomic status, ignorance of parents and stereotype thinking of families prevailing in the Pakistani society, females face difficulties in getting higher education. Mostly stereotype families want their females to be limited within the four walls of homes. Females are kept away to continue their higher education in Pakistani society (Hamid, 1993). However, interestingly, Organization for Economic Co-operation and Development (OECD) point out in 2008 that ratio of females' higher education is increasing as time passes and ratio of females in higher education is also rising as compared to men in Pakistan. The inequalities to the detriment of men would be well 
entrenched at the aggregate level by 2025, with some 1.4 female students for every male. In some countries such as Austria, Canada, Iceland, Norway, and the United Kingdom, there could be almost twice female students as compare to male (OECD, 2008). The above discussion implies that especially in Pakistan and generally at international level, there is need to take some policy measures that help to overcome this dilemma through encouraging females' progression in higher education. Since more than half of the world's population comprises on females, therefore without females' involvement dream of world's development would be incomplete.

The findings of the present study show that unavailability of universities in remote areas is also a big hurdle in females' way to progress in higher education. Parents do not want their daughters to go out of their homes and reside in hostels due to the security reasons. It is also concluded that stereotype families do not want to send their daughters in coeducational institutes because parents are scared that their daughters may adopt bad company and this would lead them towards a liberal life in which they would be able to take bold decisions regarding their lives. If they are married, their husbands and in-laws are not supportive in carrying their higher education because of the stereotype thinking of their husbands. In this type of conservative atmosphere, females cannot continue their higher education in co-educational institutes. So, it is suggested that there would be at least a university at district level and its campus/sub-campus at tehsil level.

In present study, both qualitative and quantitative data was collected from female students of the university. It is suggested for the future research that data may be collected from parents and husbands (in case of married girls) as well because they are the stakeholders and females are dependent on them generally. If parents are literate, their views can be more interesting that why they do not want to educate their daughters and what are the reasons to restrict their daughters from higher education.

Priority is always given to the boys and girls are always pressurized by saying that you are a girl so you are not allowed to do this. And if a girl is married, her husband could also give this reason that how they can manage their families when their wives are in universities or do a job. Low ratio of females in higher education cannot be increased without giving awareness to them and their families. Pakistani society needs to adopt modern school of thought regarding gender where gender equality is considered as prime important in policy making regarding every aspect of life in order to make the position of females strong.

Males usually play leading roles everywhere whether it is the domestic or professional matter. Everything is done according to the wish of males, for example in almost every home everything is cooked which is liked by males even if that is disliked by female members but no one cares, and females also understand always their responsibility to sacrifice because of societal culture. Male should acknowledge the importance of females' 
higher education and females should also take part in societal activities and confidently face the problems in their lives instead depending on males.

President, Prime Minister and the Political leaders should take the progression of females' higher education as personal concern; this will also send a positive message in the society regarding gender equality. Females' higher educational issues should be debated at parliamentary level so that precautionary measurements could be taken to avoid the barriers in the way of females' higher education.

It is important to state here that despite the efforts of some NGOs towards females strengthening, no considerable change can be seen to up-lift a females' status or even to make the general public more helpful for the prerequisites of the female acceptance in all walks of life. The females' higher education conditions are pretty much the same as in other aspects of life, females are facing sexual segregation in different structures. There are different explanations for these disappointments, in the same way as the patriarchal personality set of society, misinterpretations of Islam by fundamentalists, unfair enactments and the nonattendance of legitimate execution of females' related laws. Pakistani public sector has financial constraints, so private sector needs to share their responsibility and work for the benefits of females in order to uplift their country.

Finally, since females are discouraged at their grass root level when they are at primary level and they are restricted to go up to the higher level of studies. So, it is suggested that rigidness in the way of females' higher education should be eradicated and minds of parents/society need to be broadened in order to enable females to move in society and to make a strong position among males. The above debate demands that work on both short run and long term policies is needed that would change the traditional views of society and adopt coherent approaches and practices along with political commitment and financial investment to empower the females.

\section{References}

Bartky, S.L. (1990). Femininity and Domination. Studies in the Phenomenology of Oppression, New York, NY: Routledge.

Buchmann, C. \& Hannum, E. (2001). Education and Stratification in Developing Countries: A Review of Theories and Research. Annual Review of Sociology, vol.27, pp.77-102.

Colclough, C., Rose, P. \& Tembon, M. (2000). Gender Inequalities in Primary Schooling: The Roles of Poverty and Adverse Cultural Practice. International Journal of Educational Development, vol.20, pp.5-27. 
86 Problems of Females' Progression in Higher Education: Perceptions of Female University Students

Crapo, H.R. (2000). Cultural Anthropology Understanding Ourselves \& Others, $M c$ Graw-Hill Companies, Inc; New York, USA.

Datnow, A, Hubbard, 1. \& Conches, G. (2001). How Context Mediates Policy: The Implementation of Single Gender Public Schooling in California. Teachers College Record, vol.103:2, pp.184-206.

Dhakku, N.A., Abbasi, A. \& Iqbal, A. (2012). Small Town Problems Higher Education Remains a Dream for Many Online Journal. Retrieved from: http://www.dawn.com/news/694841/small town problems higher educationremains a dream for many.

Fredrickson, B.L. \& Roberts, T. (1997). Objectification Theory: Toward Understanding Women's Lived Experiences and Mental Health Risks. Psychology of Women Quarterly, vol.21, pp.173-206.

Hamid, S. (1993). A Micro Analysis of Demand-Side Determinants of Schooling in Urban Pakistan. The Pakistan Development Review-part II, vol.32:4, pp.713- 723.

Heise, L., Ellsberg, M. \& Gottemoeller, M. (1999). Ending violence against women: population reports. 27(4). Population Information program Centre for Communication Programs, The Johns Hopkins University.

Herz, B. \& Sperling, G.B. (2004). What Works in Girls' Education. Evidence and Policies from the Developing World, New York: Council on Foreign Relations.

Himayatullah \& Parveen, S. (1990). Interrelationship between Population and Status of Women. In: J. Rural Dev. and Administ. (JORDA), Pak. Acad. for Rural Dev, vol.22:2, pp.113-119.

Hirway, I. \& Mahadevia, D. (1996). Critique of Gender Development Index Towards an Alternative. Economic and Political Weekly, vol.31, p.43.

Keng, C. (2004). Household Determinants of Schooling Progression among Rural Children in Cambodia. Int. Education, J., vol.5, pp.552-561.

Khalid, H.S. \& Mukhtar, E.M. (2002). The Future of Girl's Education in Pakistan. A Study on Policy Measures and Other Factors Determining Girls' Education, Report, UNESCO, Islamabad. 
Khan, A. (2007). Gender Issues in Higher Education in Pakistan. Maktaba Jaded Press, Islamabad, Pakistan.

Khan, R.E.A. \& Ali, K. (2005). Bargaining Over Sons and Daughters' Schooling. Probity Analysis of Household Behavior in Pakistan, Working Paper 01-05, Department of Economics, Islamia University, Bahawalpur, Pakistan.

Mathur, S., M. Greene \& Malhotra, A. (2003). Too Young to Wed: The Lives. Rights and Health of Young Married Girls, ICRW: Washington D.C.

Mehretu, P. (2001). The Plight of Women in the Margins of Rural Life in Africa; The Case of Zimbabwe. Globalization and Marginality in Geographical Space. A Political, Economical and Social Issue of Gender Development in the New Millennium, pp.279-293.

National Council on Tertiary Education. (2006). Statistics on Faculty and Administrators in Public Universities in Ghana. National Council of Tertiary Education, Accra, Ghana.

Pakistan National Plan of Action for Women (1998). Inclusion of Violence against Women in Other National Plan/Strategy. Government of Pakistan.

Organization for Economic Co-operation and Development (OECD) (2008. Annual Report. Paris. France.

Parveen, S. (2008). Female Education and National Development, as Viewed by Women Activist and Advocates. The Bulletin of Education and Research. vol.30, pp.33-41.

Punjab Bureau of Statistics (PBS) (2005). Punjab Development Statistics. Govt. of the Punjab, Lahore.

Ramachandran, V. (2010). Gender Issues in Higher Education. Advocacy Brief. Bangkok: UNESCO Bangkok.

Rizvi, F. (1980). Background of Vocational Education for Girls. The National Conference on Critical Issues Concerning Women in Education, March 29-April 03, 1980, Women Div. Govt. of Pakistan, Islamabad.

Ronning, A.H. (2000). Gender, Culture and Power-Sharing in Academia. Women, Power and Academy: From Rethoric to Reality, Paris, UNESCO. 
Rossi, A.S. (1987). Co-Education in a Gender Stratified Society. Educating Men and Women Together, Chicago: University of Illinois Press, pp.11-34.

Sathar, Z., Cynthia, L. \& Haque, M. (2000). Investment in Children's Education and Family Building Behavior in Pakistan: Findings from Rural NWFP and Punjab. Islamabad Population Council.

Skalli, L.H. (2001). Women and Poverty in Morocco. The Many Faces of Social Exclusion. Feminist Review, vol.69, pp.73-89.

Stephan, K. (2002). Does Gender Inequality Reduce Growth and Development? Evidences from Cross-Country Regressions. World Bank Policy Research Report Working Paper Series No. 7.

Sticht, T. (1994). Family Literacy. A World Movement, Paris, France: UNESCO.

Sticht, T. \& McDonald, B. (1990). Teach the Mother and Reach the Child. Literacy across Generations, Geneva: UNESCO.

Tembon, M. \& Fort, L. (2008). Girls' Education in the 21st Century Gender Equality. Empowerment, and Economic Growth. Washington.

Terry, G. \& Thomas, T.B. (1997). International Dictionary of Education. London: Kogan Page.

Dr. Muhammad Amin is an Assistant Professor in the Department of Education, University of Education, Lahore.

Dr. Ijaz Ahmad Tatlah is an Assistant Professor in the Department of Education, University of Education, Lahore.

Ms. Arfa Afghani is M.Phil Scholar in the Department of Education, University of Education, Lahore. 